\title{
EVALUATION OF ADENOSINE TRIPHOSPHATASE IN THE STRIA VASCULARIS AND SPIRAL LIGAMENT OF THE NORMAL GUINEA PIG
}

By

Toshitaka IINUMA, M.D.

From the Department of Oto-rhino-laryngology, Faculty' of Medicine, University of Tokyo, Japan

(Director: Prof. Ichiro Kirikae)

The enzymatic ATP-hydrolyzing system in the stria vascularis and spiral ligament of the normal guinea pig was investigated. The existence of membrane ATPase, which is said to be closely related to the active transport of sodium and potassium across biological membranes, was established. The membrane ATPase in the present study was found to be similar in many respects to that found in various tissues.

The activity of the membrane ATPase in the stria vascularis and spiral ligament was considered to be fairly high in comparison to other secretory tissues. The distribution of the enzyme activity among various portions of the membranous labyrinth was also demonstrated.

\section{正常モルモツト血管条および螺旋靬带における}

\section{Adenosine Triphosphatase $の$ 测定}

東京大学医学部耳奥㸶㮢科学教室（主任: 切替一郎教授）。

大学院学生 飯 沼 奉衫

目次

1. 緒晋

2. 実験方法

1) 組織分離法

2) 蒋品

3) 醉菜測定法

4) 乾燥重量测定法

5) 統計処理

3. 実験結果

1) Ouabain の影餐

2) カリウム及びナトリウム溲度の影蚃

3）マブネシウム怙よびカルシウム浱度の影蓄

4) 温度および $\mathrm{pH}$ の影響

5）種々の阻害凨の影響

6)螪牛各超転別および膜迷路の他の部分に㧍ける 䤃素活性

7）血管系のみの酵素活珄
4. 検剧

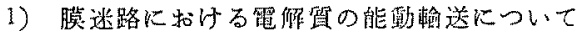

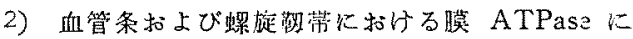
วいて

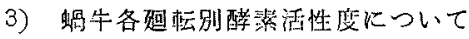

5. と め

\section{1. 緒 言}

化学的微量定量法つ発趡に上つて，過去 10 年間汇内 リンパ特よび外リンパの組成分析がなされた。これらの 分析結果は内耳の機能を理解するに重要であることも判 明してきた。内耳液に批るる霓解質の分析は 1954 年に 始めて，Smi(h 他1)によつてなされ，モルモット内り ンパの高カリウム漶度扣よび低ナトリウム漲度，また外 リンパ組成の他の細胞外液との類似などが示された。

これと似た所見が他の種類の怔物，すなわち，猫， (Citron 他 $\left.{ }^{2)}\right)$ ，人，(Rauch 他 ${ }^{3)}$ )，モルモット，(三 宅出), 亀と蛙, (Johnstone 他占), 扰よび, 魚, 


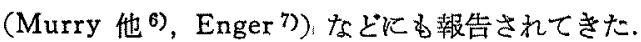

内リンパに怙ける特異な電解質の分在は能動輸送, Active Transport（イオンを膜を通じてェネルギー差, 濃度差などに打勝つてェネルギーをるらいて輸送する過 程. Ussing ${ }^{8)}$ ) によりなされることは疑いない、

ただし，膜迷路のどの部分でこの能動輸送が行なわれ るかについては多くの議論があり定説がない，また、こ の問題は内リンパの起原にもからまるもので, 数多くの 報告から内耳液の起原扎よび吸収に関する定説を見いた すのは困難なようである (Lawrence, ${ }^{9}$ )).

しかし，これらの極め難い議論にもかかからず，血管 条拉よび螺旋隺帯 (Vosteen,10))，あるいはライスネル 氏膜 (Rauch, II) および Chou, 12)) などの果す役割は 認められた。

これら歴定的経過を考虑に入れ，我ふは血管条和よ び螺旋勒帯に礼ける1つの醉素系を础究して来た。 こ れは Adenosine Triphosphatase (ATPase) の1つで あつて生物学的膜を通して，カリウムとナトリウムの

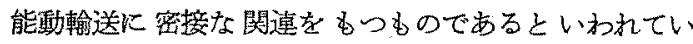
る. ATPase は Adenosine Triphosphate (ATP) Adenosine Diphosphate (ADP) と無機りン酸洮解 する際，作用する酵素である。この際に登生した高エネ ルギーは，さまさまな生物の活動，例えば筋収縮，能動 輸送などに用いられるという。

神経膜 (Caldwell 他 ${ }^{13)}$ ), 赫血球膜 (Whittam, 14) および Hoffman, 15) に括ける実駼から能動輸送汇必要 なエネルギーは ATP から来ることが示された。 Skou

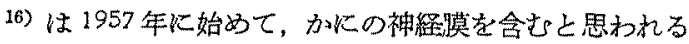
ミクロソーム分かくに执いて，ある種の ATPase の活 性がカリウムとナトリウムの共存によつて活性化される ことを発見した。

このカリウムおよびナトリウムで活性化される AT. Pase 成分は同時に Ouabain (=Strophantin G) によ り阻害される。これより先 1953 年に Schatzmann, ${ }^{17}$ ) は Ouabain がカりウム拈よびナトリウムの輸送を阻㬐 することを観察している：この ATPase 成分が，少く とも一部分は，カリウムお゙よびナトリウムの能䡃輸送に 関連することが考えられた。

Post 他 ${ }^{18)}$ 执よび Dunham 他 ${ }^{19)}$ は赤血球に扮いて ATPase 活性と能勩輸送に極めて 密接な関速のあるこ とを訨明した，网者，すなわら ATPase 特よび能䡛輸 送结，膜に局在し，雨者ともATP を使用し，雨者に カリウム、ナトリウムの存在が必要であり，さらに両者
とも特異的に Ouabain で阻害される。このようにカリ ウムとナトリウムで活性化され，しかも Ouabain で特

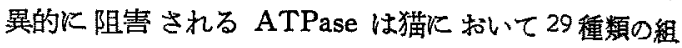
蟣に 㹬明され，広く生物内に 分布することが示された (Bonting, 他 ${ }^{20)}$ ).

現在この ATPase は種々な名称で呼ばれており， rMembrane ATPase $\rfloor$ Glycoside or OuabainSensitive ATPase」, rSodium-Potassium-ActivatedATPase」扎よび rPump-ATPase」などがある，当論

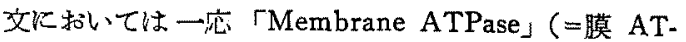
Pase）と眖ぶことにするが，これは必ずしすただつの 醇素系が存在することを意味するとは限らない，

今回の論文は正常成熟モルモットにおける血管条扰よ び螺旋靭带の膜 ATPase およびその他のATP-水解系 の測定を報告するものであり，この要旨は1965 年11月 に米国シカゴで行なわれた「第 9 回全米耳鼻咽啹私基礎 部門研究発表会（米国耳奥咽喉和アカガミー主催)」に て発表された(飯品 $\left.{ }^{21}\right)$ ） ストレプトマイシン系統の内 耳中毒性薬物のこれら醉素系への可能性ある影響につい ての報告が続いて行なるれる(飯沼 ${ }^{22)}$ )。

\section{2. 実験方法}

1) 組織分離法

正常耳介反射を示す成熟モルモットが用いられる。モ ルモットは約 $50 \mathrm{mg}$ の Pentobarbital Soduim の腹腔内 注射で麻酔され，断頭される。取り出された側頭骨はす 及やが头冷された Ethylene-Diamin-Tetra-AcetateDisodium (EDTA)， $2.5 \mathrm{mM}$ 褿度溶液に保たれる。 EDTA 溶液は Trishydroxymethylaminomethane (Tris) にて pH7.5 に調節されてある。

15 倍立体顕徽鏡下に血管条亡螺旋勒带はともに取り 出され，氷冷 EDTA 溶液内に保たれる．EDTA 溶液 は組織片よりカルシウムイオンを除く目的で使用される

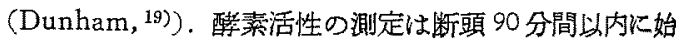
められる，予備实験結果によれば，水冷 EDTA 溶液内 にて 90 分間保存することは䣼素活性に認めるべき变化 を与充ないことが判明している。

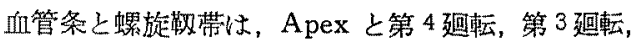
第 2 迴轱叔上び第 1 迴転の4つの部分にわけて取り出さ れる，第1廹耺においては骨螺旋板の紌い骨片が分離さ れた組織片に附着し，容易に取り除けない，後にのべら れるごとく，酵素活性は乾燥重量 $\mathrm{mg}$ あたりに換算さ れるために，この細小骨片の附着は重大な誤差の原因に なり得る．從つて今回の諭文では，第 1 廻転の活性は参 
考迄火引用され，純計処理に上り算出される全迥転の平 均活性度には含まれない。

2) 薬品

ATP (Disodium salt) および Tris-ATP は Sigma Chemical Co.上り購入された。. Ouabain 扰よび Oligomycin は Mann Research Laboratories より購入さ れた。他の日常楽品, $\mathrm{NaCl}, \mathrm{KCl}, \mathrm{Mg} \mathrm{Cl}$ などは Reagent Grade である. 薬品はすべてがラス再蒸溜水にて 準桶された．また室温保存で変化を受ける物質は使用さ れるすで水結された，以上の藩品内に微量に存在する重 金属は特に分離されなからた。

3) 醇素測定法

種々な反応系の組成はをの都度图表に执いて説明され る.最終反応系容積は $1 \mathrm{ml}$ である. 螖牛の1廻転分の 組緇片は小さなガラス鉿で釣り上げられ，小試験管内の

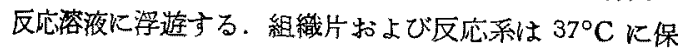
大れ，30 分後に10\%水冷 Trichloroacetic Acid (TCA) を $1 \mathrm{ml}$ 加えることにより反応を止める。乾燥重量測定 のため，再び蒸溜水にて洗つた後，組織片はプレパラー トの上にのせる。

1.Oml の反応液は Fiske, SubbRow 法 ${ }^{23)}$ の変法に

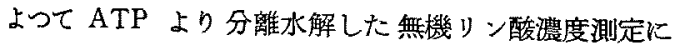
用いられる。 Beckman DU 型光電比色計および微量定 量用七ル $(0.9 \mathrm{ml})$ を用いる，当実験条件下では，組織 片自体には無機りンは存在が証明されない，組織片を含 ま奴反底糔醇反応以外の ATP 分解の補正のため コントロールとして同し状態で観察される，反応系の時 間㧍よび組織重量に関する直楾性については予備実験に 拉いて確かめられた。

醇素活性度は乾橾重量 $\mathrm{mg} ， 1$ 時間あたりATPより 水解された無機りン量 micromole で示される（Pimicromoles/mg dry wt./hr).

\section{4) 乾燥重量測定法}

反店終了後組織片を再蒸溜水で洗い，プレパラートの 上にのせ, 気温 $25^{\circ} \mathrm{C}$ ，湿度 $30 \%$ 以下のドラフトに 48 時間放㽎して乾燥重量とする。乾燥重量仕 Helix, Quartz Balance (Microchemical Specialities Co) を用 いて㴬定する．この感度は $1.0 \mathrm{~mm}$ の延長あたり 16 マ イクログラム $\left(=10^{-6}\right.$ gram $)$ に相当する。湿度との関保 は少く，詳細な検討は Lowry ${ }^{24)}$ を参照されたい。

5), 統計処理

以下の分析で明らかほなることとく，膜 ATPase の活 性は, 反応系比 Ouabain が存在する場合としない場合
の平均值 (Sample means) の差として表現される。一 般の定㼁によれば，この差が確摔 0.95 以上の場合，差 は有意義であるという (Solomon 25) および Weiner 26)）。以下にのべるごとく，膜 ATPase の同定にはさ まざまの反度を用いなければならず，その各々と統計 的処理を可能にする多数の実験を重ねるこ之は挬術的比 困難である。従つて Ouabain にのみ限つて、拉よそ25 例の実駼を重ね，統計処理を行つて，膜 ATPase の存 在を明らかルし，その後の各種の反応系に関しては6〜 10 例を用い，平均值を示す。

\section{1) Ouabain の影響}

\section{3. 実験結果}

膜 ATPase の活性は $0.2 \mathrm{mM}$ Ouabain の存在で完 全记阻害されるという (Post 他 ${ }^{18)}$ )。従つて膜 ATPase の活性度は，Ouabain の存在する反応系の活性度を Ouabain の存在しない、反度の活性度から苛いた差で 表現される。

图 1 酵崒活性测定値分布

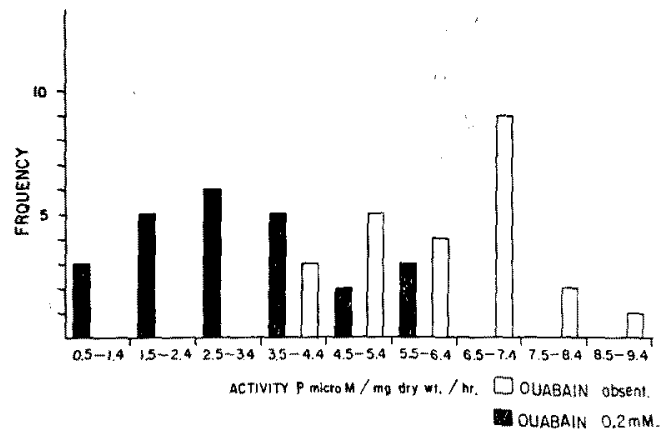

湿度 $37^{\circ} \mathrm{C}$. pH7.5. ATP $2.5 \mathrm{mM}$. Na $85 \mathrm{mM}$. K $30 \mathrm{mM}$. Mg $2.5 \mathrm{mM}$. Tris $20 \mathrm{mM}$. すべて 最終濃度を示す。值は，Apex 第 4 迴枟，第 3超転扰よび第 2 题転の平均值である。

図1《示されるごとく，これら活性の実測值の分布は ほほ正規分布を示し，このことから正規分在江閔する統 計分析がなされる。

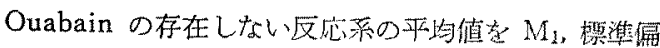
差を $S_{1}$, Ouabain の存在する反沈系のものを各々 $M_{9}$ 扣よび $\mathrm{S}_{2}$ とすると， $\mathrm{M}_{1}-\mathrm{M}_{2}=2.1$ が観測された差に なる。すすなわち膜 ATPase の活性度である。 $\mathrm{S}_{1}=1.4$, $\mathrm{S}_{2}=1.5$ であるから, 美の㮦㩐呮差, SEd (Standard

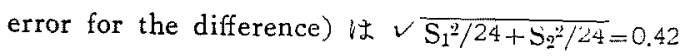
となる、統計法によ机ば (方法参照)，( $\left(M_{1}-M_{2}\right) / S E d$ 
が2より大きければ， $\left(\mathrm{M}_{1}-\mathrm{M}_{2}\right)$ ，すなわち、2つの反応 系の差は 0.95 以上の確率をもつて確かであるとい5. 現在の場合この值は約 5 であつて，統計的にこの差は有 意義である。従つて膜 ATPase の存在は確率 0.95 以 上をるつて証明された。

2）カリウム括よびナトリウム賑度の影響

図 2 特よび図了に示されるごとく，ATP の醭素的水 解系には 2 つ成分が存在する１１つはその活性がカリ ウム拉よびナトリウムの㵊度上舁と其に上るるので，こ の上昇分は Ouabain $0.2 \mathrm{mM}$ の存在で阻害される。 む 51 つは電解質濃度や Ouabain で影響を受けない系で ある，前者がいかゆる膜 ATPase に相当する，後者は Ouabain-insensitive Component と呼ばれる.

図 2 カリウム擞度のATPase 活性度への影響

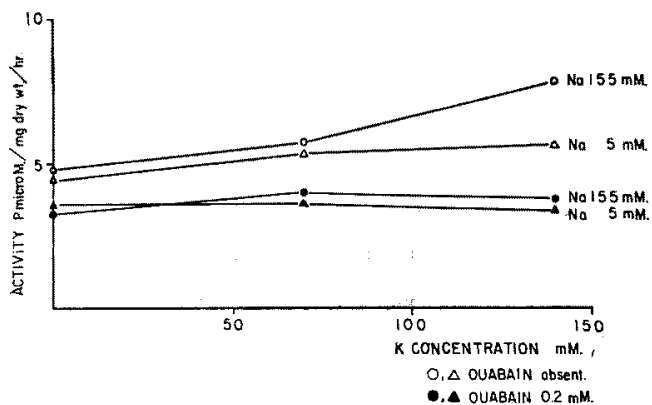

温度 $37^{\circ} \mathrm{C} . \mathrm{pH} 7.5$. ATP $2.5 \mathrm{mM} . \mathrm{Mg} 2.5 \mathrm{mM}$. Tris $20 \mathrm{mM}$.すべて最終呩度示す。各点は Apex と第 4 迴枟，第 3 廻枟，第 2 迴転の平均 值である，測定は各点 6 䇠の側嘼骨の平均でな された。

图 3 ナトリウム浱度の ATPase 活性度 への影每

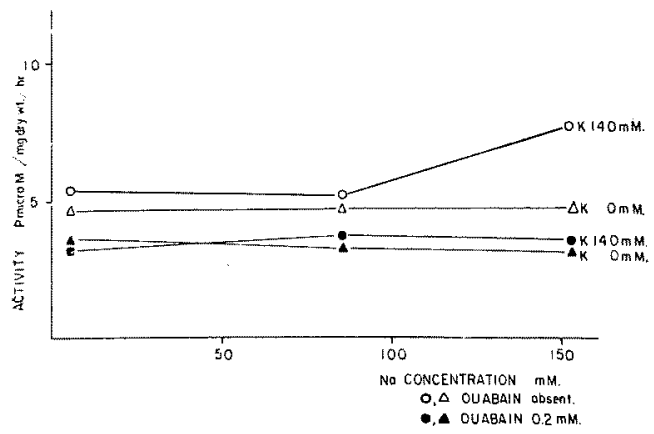

温度 $37^{\circ} \mathrm{C}$. pH7.5. ATP $2.5 \mathrm{mM} . \mathrm{Mg} 25 \mathrm{mM}$. Tris $20 \mathrm{mM}$. すべて最䅂源度を示す. 各点 6 简 +の側頭骨の平均，図 2 参照。

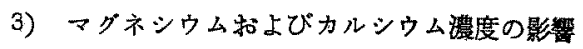

図 4に示されるごとく，マグネシウムの濃度が ATP と等しい時，膜 ATPase の活性は最高を示す。实験 範围内では Ouabain に影響されない成分 (Ouabaininsensitive Compont) はマダネシウム濃度にも関係が ない。

図5によれば，カルシウムはマグネシウムと共存する 時, 膜 ATPase を阻害する。 Ouabain に影響されない 部分はカルシゥム澧度にも影響されない。

图 4 マグネシウム濃度の ATPase 活性度 への影響

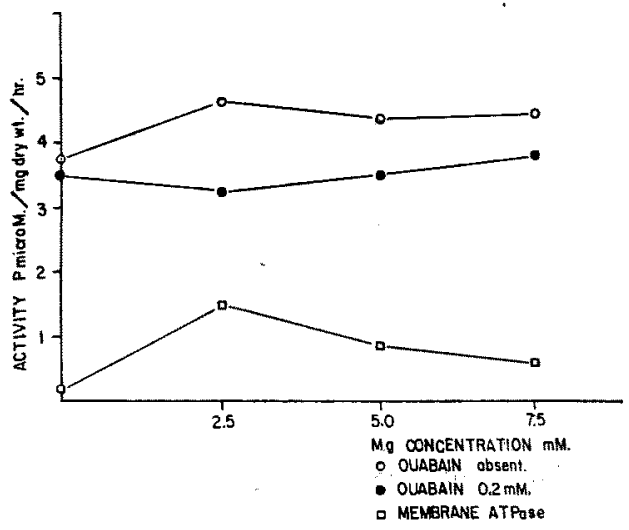

温度 $37^{\circ} \mathrm{C} \cdot \mathrm{pH} 7.5$. ATP $2.5 \mathrm{mM}$. Na $25 \mathrm{mM}$. K $140 \mathrm{mM}$. Tris $20 \mathrm{mM}$. 各点 6 䌪の㑬頭骨の 平均. 図 2 参照.

图 5 カルシウム濊度のATPase 活性度 への影琶

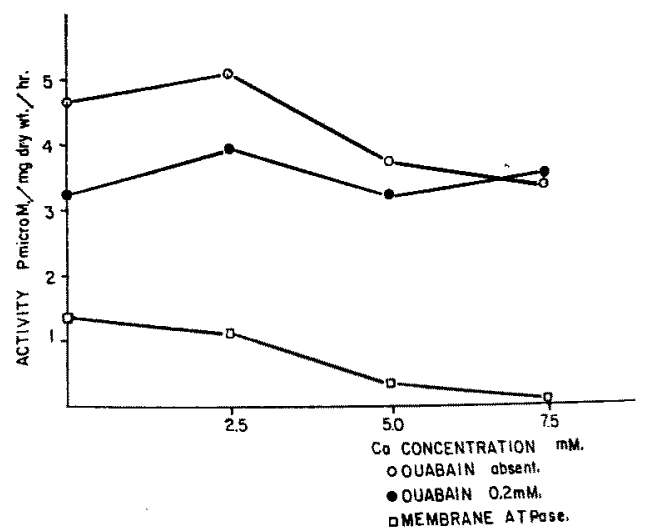

温度 $37^{\circ} \mathrm{C}$. pH7.5. ATP $2.5 \mathrm{mM}$. Na $25 \mathrm{mM}$. K $140 \mathrm{mM}$. Mg 2.5mM. Tris 20mM. 各点は 6 管の側頭骨の平均. 因 2 参照. 
4) 温度和よび $\mathrm{pH}$ の影響

因6によれば低温，高温両者ともに膜 ATPase の活 栍低下をきたすが，Ouabainで影響されない成分は $42^{\circ}$ C まで活性が温安上昇と共と上る。酵菜的 ATP 水解 全体としての活性は $37^{\circ} \mathrm{C}$ で最高を示す。

図7によれば，pH 7.5 からいずれのう向にずれても， 膜 ATPase の活性は低下し，それに反して Ouabain

因 6 温度の ATPase 泟姓度一の影裂

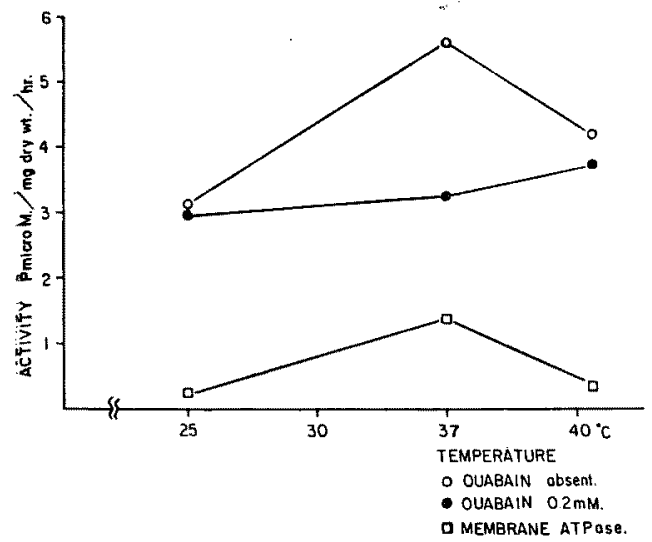

pH7.5 ATP $2.5 \mathrm{mM}$. Na $25 \mathrm{mM}$. K $140 \mathrm{mM}$. Mg $2.5 \mathrm{mM}$. Tris $20 \mathrm{mM}$. 各点待 6 筒の側頭骨 の严均值. 図 2 参照.

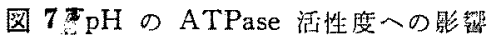

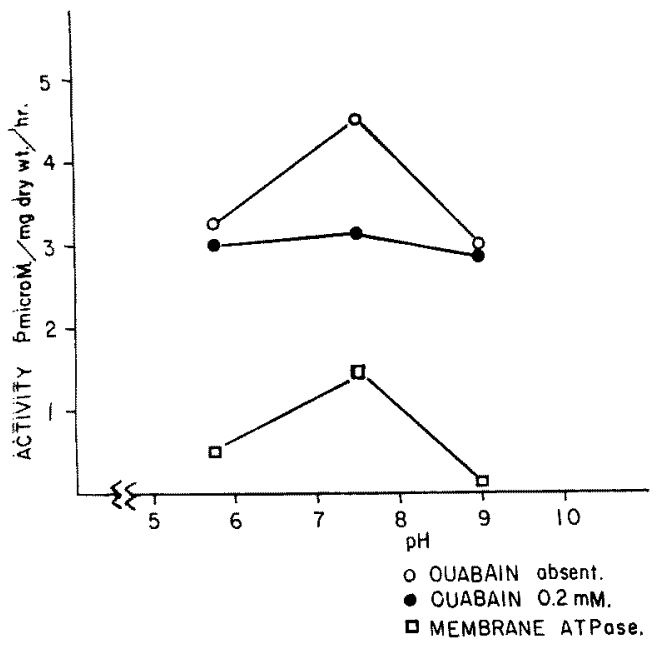

温婪 $37^{\circ} \mathrm{C}$. ATP $2.5 \mathrm{mM}$. Na $25 \mathrm{mM}$. K 140 mM. Mg. $2,5 \mathrm{mM}$ Tris $20 \mathrm{mM}$. 各点は6 筒の

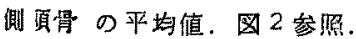

に影響されない成分は $\mathrm{pH}$ の变化见も余り影響をうけ ない.

5)種々な阻管㶡の影響

表りによれば，今回の測定条售下に拈いては，2，4Dinitrophenol (DNP) および Oligomycin は ATP

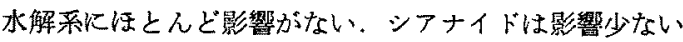
のに区してフルオライド心相当に ATP 水解系阳彗 する。

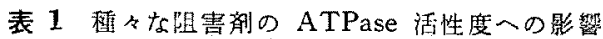

\begin{tabular}{|c|c|c|c|c|}
\hline INHIBITORS. & $\begin{array}{l}\text { DNP } \\
0.1 \mathrm{mM}\end{array}$ & $\begin{array}{c}\text { Oligom ycin } \\
\mathrm{Ir} / \mathrm{ml}\end{array}$ & $\begin{array}{c}\text { Cyanide } \\
10 \mathrm{mM}\end{array}$ & $\begin{array}{l}\text { Fluoride } \\
10 \mathrm{mM}\end{array}$ \\
\hline 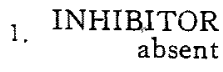 & 3.8 & 3.5 & 3.3 & 4.0 \\
\hline $\begin{array}{l}\text { 2. INHIBITOR } \\
\text { present }\end{array}$ & 3.9 & 3.6 & 3.4 & 2.8 \\
\hline $\begin{array}{l}\text { 3. Difference. } \\
(1, \sim 2 .)\end{array}$ & 0.1 & 0.1 & 0.1 & 1.2 \\
\hline
\end{tabular}

ACTIVITY Pmicro $\mathrm{M} / \mathrm{mg}$ dry wt./hr.

温等 $37^{\circ} \mathrm{C} . \mathrm{pH} 7.5 . \mathrm{Na} 25 \mathrm{mM} . \mathrm{K} 140 \mathrm{mM}$.

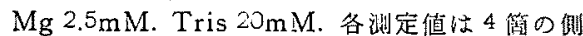

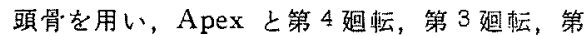
2 迴転の平均值を示す。

图 8 膜迷路に拈ける活性度分柯

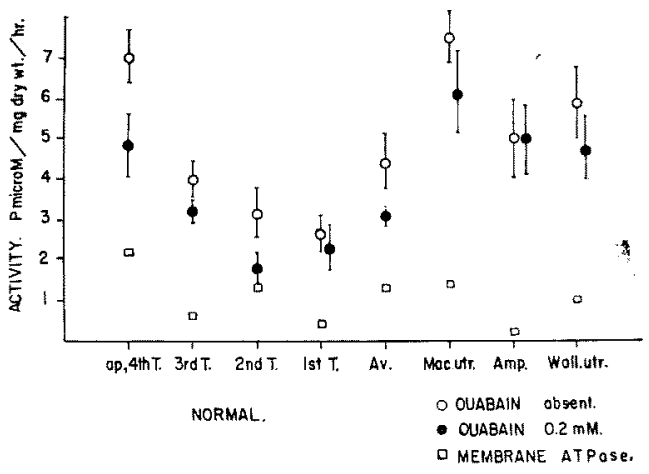

湿度 $37^{\circ} \mathrm{C} . \mathrm{pH} 7.5 . \mathrm{Na} 25 \mathrm{mM}$. K $140 \mathrm{mM}$. Mg. 2.5mM. Tris $20 \mathrm{mM}$.

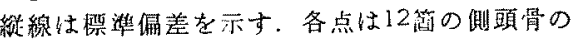

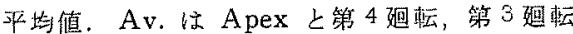

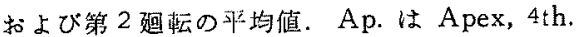

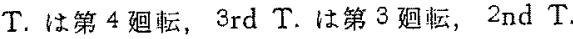

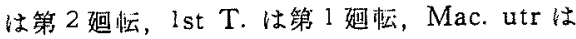
Macula utriculi, Amp. は Ampulla semica nalis, Wall u:r は Utricle の壁を指す. 
6）螖牛廻転別批よび膜迷路の他の部分に 打ける䤃素活性

因8は膜迷路の種々な場所における睹素活性の分布を 示す。ナトリウム扣よびカリウムの濃度は内リンバ液の それに相当する. 膜 ATPase に関する限り, 螖牛迴転 別の活性度分有仙迴転に従つた順序の分布は示さない， ただし，醉素的 ATP 水解系全体としての活性忹第 1 廻転から A pex 飞行くに従つて上笔寸る。前庭末梢系 の活性度も相当湾高い。

7）血管条のみの醭素活性

以上の結果はいず机も血管系と螺㺼勒帯を共にした組 糡から算出された．第 1 ，第 2 迴転は別とし血管系を螺 旋鞋带から分離することは困難であり，たとえ分離でき ても組織片が小さすぎて重量が測定不可能になる。 そこ でモルモット15匹30耳を使用し，第2 迴転のみに和い て，血管条と螺旋勒带との活性を別策に 測定した。 そ れによれば，血管系の ATP 水解系全体の活性は9.1 であり，その内，膜 ATPase が 2.8, Ouabain に影響 を受け奴成分が 6.3 である。をた，螺旋鞋帯の活性度は ATPase 水解系全体として 1.7, その内, 膜 ATPase が0.1，Ouabain に影響されぬ成分が1.6である。 こ のように，少くとも第2 迴転に执いては，血管条の活性 は螺啶带叔の活性に比して極めて高い，換言すれば現在 の実験条件では大部分の活性は血管条に由来し約 $1 / 5$ 見 当の活性が螺擬嗼帯より由来するものと思われる.

\section{4. 検 討}

1）膜迷路に打ける電解貿の能動輸送について

内耳液の分泌括よび吸収に関しての知識は現在完全な あのではないが，大きく分けて，膜迷路には3っの組合 せが恐らく能動輸送に関連するのではないかと思われ る. 1 つは血管条と螺炡靶帯（別䇫に，あるいは共沉）， ライスネル氏膜，あるいは以上の組合せ等である。

Guild 27)の行つた 古典的実験以来，血管条枕りン パ分泌の観点から研究対象として取りあげられて来た。

種々の組織化学的染色法によれば (Vosteen, $\left.{ }^{10}\right)$ ), 血管 条の反応は相当高度の物質代謝を反映するかのようで ある。Rauch 他 1)に上机ば放射性カリウムを使用し ての实験では血管条似は吸收作用が存在するという。

Choo 他 28) 23) の結果では，放射性カリウム，ナトリウ ムを用いての实験において，相当に高度な分泌作用を認 めたという。

Engström 他 ${ }^{30)}$, Smith ${ }^{31)}$ および Iurato ${ }^{32)}$ 等の電 子顕徽鏡の所見によれば，血管条には液体の分泌ないし
は吸収を裹付けする形態学的根拠があるといら。

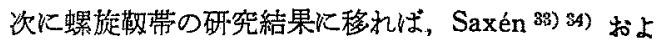
び Borghesan ${ }^{35)}$ は特に Outer Sulcus が内リンぶ循 環に密接な関連をるつとい5. Butler, 他 ${ }^{36)}$ は Spiral Prominence に特殊な陰電負荷状熊を観察し，内リンハ 循環との関連を討論した.

最後にライスネル氏膜はその透過性を主題として研究 が進められてきた。 Rauch，他 ${ }^{11)}$ に上れば，放射性の カリウムはライスネル氏膜を通して濃度差に打勝つて, 放射性 ナトリウムの約 5 倍以上の 速度で䔟動するとい 万. 又 Chou 12) の行つた酸素消費量の測定に上れれ゙， ライスネル氏膜の消費量は血管条に比すべく，しかも腎 皮質，脳皮質上りは高いとい5，Lawrence，他 ${ }^{37) に ~}$ よると，ライスネル氏膜もまた，電子顕微鏡的所見から 解釈して撰択的な通過をつかさどる組織であるという．

以上のごとく、ごく最近の論文を引用するだけで㦈論 はます主発展して、いずれがいずれとも判定し難くな って来る，現在までのところ，血管条，螺颃路带，それ からライスネル氏膜のいずれる能動輸送の立役者たりら る種々の条件をそなえているかの上らに思われる。

今回の実験は能動輸送の所在についてはなんの検討も できない，すなわり，技術的問題（主に重量測定）から ライスネル氏謨が湘定に含まれていないまた，血管条

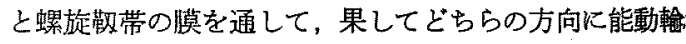
送が㗢くかについても討論できない。

今回の報告は，生化学的に能動輸送に密接な関係を有 すると思われる酔素の存在を証明したにすきない。

他の報告例と比較し，血管条と螺该靶带の膜 ATPase の活性は相当に高い。

実験状態が異る報告例が多く，正確な此較はできない が，大体腎皮質の約 $1 / 2$ の活性を有する．雨皮質のデー タは Whittam, 他 ${ }^{37}$ による。猫の種々な緝織におい て試みられた膜 ATPase 活性度による分類法によれば (Bonting, 他 $\left.{ }^{20}\right)$ )，血管条之螺旋敬夢の活性度は，choroid plexus, ciliary body, 执よび胃粘膜と比局する.

2）血管条和よび螺旋䩒帯に和ける 膜 ATPase について

今回の報告で，姐管策と螺旋䩓带に存在を踣明された 膜 ATPase は他の動物の種々な組織に 証明されたもの と性質を共炕する点が多い、すなわち，陽イオンの必 要性 (Skou 16), Post, 他 ${ }^{18)}$ および Dunham. 他 ${ }^{19)}$ ), Ouabain に対する感受性 (Skou 16) および Dunhain 19)），カルシウムの阻帮 (Skou $\left.{ }^{16)}\right)$, などである. 
生化学的に検討を進めた場合，血管条と螺旋靯带に括 ける膜 ATPase は，以上の諸条件を満たすことから， カリウム和よびナトリウムの能動輸送に密接に関連して いることと思われる。 Olgiomycin と DNP は酸化的 リン酸代謝 (oxidative phosphorylation) の阻害斉で あるが，両者ともに今回の実験条件ではほとんど影響が ない, Oligomycin はまた一方, 極めて低濃度（1 microgram/1.0ml) で拱択的にミトュンドリアのATPaseを 阻害するとい5 (Huijing 他 ${ }^{38)}$, Töbsis 他 ${ }^{39)}$, Van Groningen 他 ${ }^{40)}$ )。 今回の報告で, Oligomycinは 1 microgram $/ 1.0 \mathrm{ml}$ で使用し, しかむATPase に影響 がみられなかつた：このことは今回の報告の ATPase の活性はミトコンドリフ以外に由来することを示すすの であるといえる. Cyanide はチトクローム $\mathrm{a}_{\mathbf{3}}$ の阻害で あるが，これはまたアルカリフオスフフターゼの阻害剂 としても知られる，Cyanide bをた今回の報告では影 響がない。

Fluoride は酸性フオスフフターゼの阻害郕であり今 回の報告では阻害を誌めた。このことはいわゆる nonspecific な phosphomonoesterase の存在を暗示するも ので,この点に関しては稿を更るて検討がなされる（飯 沼 ${ }^{41)}$ ).

Ouabain に影䍩されない、ATPase の機能的意義は現 在活とんど知られていない.

膜 ATPase に関しての更に詳しい生化学的な検討は， Hokin 他 ${ }^{42)}$, Judah, 他 ${ }^{43)}$ ，Skou 44), Csáky ${ }^{45)}$ の総 論がある。

また Ouabain に笑しては Repke ${ }^{46)} か ゙$ 最子良い。眼 科領域㷧いて緑内障との閔俰を検討した論文はより臨 床的である(Simon, 他 ${ }^{47) お よ ひ ゙ ~ 48) . ~}$

3）蝸牛各超転別醇素活性度について

Meyer zum Gottesberge 他 ${ }^{49)}$ によれば，蝸牛各趈 転別に血管条の物質代愔期明らかに美を示すといら．例 えば，酸素消費量は第 1 迴転から A pex に行くにつれ 減少し，これに反してライスネル氏膜の透過性は增加す \%.

今回の ATP の䤏索的水解系の研究によれば，水解系 全体としての活性度は第1廹転から Apex に行くに良 つて墦加を示す。

ところが，䠑 ATPase の活性は第 3迴転が低いため 今のような配列は認められない。このように第 3 迴転の 活性度が低いことに関する解鄱は困難である。

第2 迴転において明らかにされたごとくにもしも，血
管条と螺旋勒带が別籄に測定されると，血管条の活性の 方がはるかに高い，このことから Midmodiolar Section の影改鏡標本 6 つを用いて，血管条と螺旋靶帯の面積比 を算出し，兩者の比重はほぼ等しいと仮定すると，この

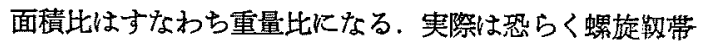
の比重の方が高いと思われる。

いま, 血管条と螺旋噶帯, これと血管条との重量比を とると，第1 迴転から第 4 迴転の順に，9.3，8.6，7.6， 4.9 となる.この此て膜 ATPase 活性度を各々の部分 について補正しても第3迴転の低活性は補正されなかつ た.すなわち，廻転の順に活性度は亚ばなかつた。

\section{5. をとめ}

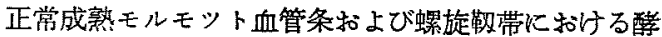
素的 ATP 水解系の活性測定が行なわれた，1価陽イオ ソ、すなからカリウムとナトリウムの能動輸送に 密接 な関係をする膜 ATPase の存在が証明された。この膜 ATPase は，神経膜，赤血球膜に存在するものと经活 同し性貿を有することが示されたた。た，血管条と螺旋 跑带の膜 ATPase 活性は, 他の分汹器官に比し高度で あることが判明した。

蛤牛廷転別，および前庭膜迷路の活性も図示された。

\section{文献}

1) Smith et al.: The electrolytes of the labyrinthine fluids., Laryngoscope, 64; 141, 1954.

Citron et al.: Formation, circulation and chemical properties of the labyrinthine fluids. Brit. Med. Bull., 12: 101, 1956.

3) Rauch et al.: Aspects chimique de l'endolymphe et de la perilymphe. Pract. oto-laryng., 20; 287, 1960. 4) 三宅: 内耳 液の研究，日耳貫; 63，1，1960。

5) Johnstone et al.: Sodium and potassium in vertebrate cochlear endolymph as determined by flame microspectrophotometry., Comp. Biochem. Physiol., 9; 335, 1963. 6) Murray et al.: The composition of the endoly$\mathrm{mph}$, perilymph and other body fluids of elasmobranchs, Comp. Biochem. Physiol., 2; 65, 1961. 7) Enger: Ionic composition of the cranial and labyrinthine fluids and saccular D.C. potentials in fish., Comp. Biochem. Physiol., 11; 131, 1964. 8) Ussing: Transport of ions across cellular membranes. Physiol. Rev., 29; 127, $1949 . \quad 9$ 9) Lawrence: Hearing, Ann. Rev. Physiol., 23; 485, 1961. Vosteen: Neue Aspekte zur Biologie und Patholo- 
gie des Innenohres., Arch. Ohren-usw.-Heilk., 178; 1, 1961. 11) Rauch et al.: Arguments for the permeability of Reissner's membrane., Laryngoscope, 73; 135, 1963. 12) Chou: Respiration of Reissner's membrane of the guinea pig., J. Laryng., 77 ; 374, 1963. 13) Caldrecll: The utilization of phoshate bond energy for sodium extrusion from giant axon., J. Physiol., 137; 12P, 1957.

Whittam: Poiassium movements and phosphate metabolism in red cells., J. Physiol., 137; 13P, 1957. 15) Hoffman: The link between metabolism and the active transport of $\mathrm{Na}$ in human red .cell ghosts. Fed. Proc., 19; 127, 1960.16 16) Skou: The influence of some cations on an adenosine triphosphatase from peripheral nerves. Biochim. Biophys. Acta, 23: 394, 1957.

17) Schatzmann: Hertzglycoside als Hemmstoffe für den aktiven Kalium und Natriumtransport durch Erythrocytemmembran. Helv. Physiol. Acta, 11; 354, 1953.

18) Post et al.: Membrane adenosine triphosphatase as a participant in the active transport of sodium and potassium in the human erythrocyte. J. Biol. Chem., 235; 1796, 1960. 19) Dunham et al.: Adenosine triphosphatase activity and the active transport of alkaline ions. J. Physiol., 156; 274, 1961. 20) Bonting et al.: Studies on sodiumpotassium activated adenosine triphosphatase. 1. Quantitative distribution in several tissues of the cat. Arch. Biochem. Biophys., 95; 416, 1961. 21) Iinuma: Evaluation of adenosine triphosphatase activity in the stria vascularis and spiral ligament of the normal guinea pig. Read at the 9th Ann. Meeting. The committee for Research in Oiolaryngol., Am. Ac. Ophthal. Otolaryng., 1965. 22) Iinuma et al:: Possible effects of various otoioxic drugs upon the ATP-hydrolyzing sytem in the stria vascularis and spiral ligament of the guinea pig. In preparation. 23) Fiske et al.: The colorimetric determination of phosphorus. J. Biol. Chem., 66 ; 375, 1925. 24) Lowry: The quantitative histochemistry of the brain. J. Histochem. Cytochem., 1; 420, 1953.25$)$ Solomon: Information and error. Basic Books Inc., New York, 1959.
26) Weiner: Bios'atisiics. New York Univ., 1965. 27) Guild: The circulation of the endolymph. Am. J. Anat., 39; 57, 1927. 28) Choo et al.: Formation and flow of cochlear fluids. 1. Studies with radioactive sodium. Ann. Otol., 73; 92, 1964, 29) Choo et al.: Formation and flow of cochlear fluids. 2. Studies with radioactive potassium. Ann. Otol., 74; 140, 1965. 30) Engström et al.: Feinstruktur der Stria vascularis. Pract. oto-laryng., 17; 69, 1955. 31) Smith: Structure of the stria vascularis and the spiral prominence. Ann. Otol., 66; 521, 1957. 32) Iurato: Submicroscopic structure of the mernbranous labyrinth. Z. Zellforsch., 52; 105, 1960. 33) Saxén: Some observations on the physiology of endolymph stream. Acta otolaryng., 74; 87, 1948. 34) Saxén: Histological studies of endolymph secretion and resorptson in the inner ear. Acta otolaryng., 40; 23, 1951, 35) Borghesan: Modality of the cochlear humoral circulation. Laryngoscope. 67; 1266, 1957. 36) Butler et al.: Cochlear functions under metabolic impairment. Ann. Otol., $71 ; 648,1962$. 37) Whittam et al.: The sensitivity of a kidney ATPase to ouabain and to sodium and poiassium. Biochim. Biophys. Acta, 51; 622, 1961. 38) Huijing et al.: The use of oligomycin as an inhibior of oxidative phosphorylation. J. Biochem.(Tokyo)., 49; 493, 1961. 39) Jöbsis et al.: Inhibition of a $\mathrm{Na}$ and $\mathrm{K}$-stimulated adenosine triphospoatase by oligomycin. Biochim. Biophys. Acta, 73; 346, 1963. 40) Van Groningen et al.: The effect of oligomycin on the $(\mathrm{Na}+\mathrm{K})$-sctivated magnesium-ATPase of brain microsome and erythrocyte membrane. Biochim. Biophys. Acta. 73; 527, 1963. 41) Iinuma: The evaluation of various phosphomonoesterases in the stria vascularis and spiral ligament of the guinea pig. In preparation. 42) Hokin et al.: Biological transport. Ann. Rev. Biochem., 32; 553, $1963 . \quad$ 43) Judah et al.: The biochemistry of sodium transport. Biol. Rev., 39: 160, 1964 . 44) Skou: Enzymatic basis for active transport of $\mathrm{Na}$ and $\mathrm{K}$ across cell membrane. Physiol. Rev., 45; 596, $1965 . \quad$ 45) Csaky: Transport through biological membranes. Ann. Rev. Physiol., 
Triphosphatase の測定

27 ; 415, 1965. 46) Repke: Über den biochemischen Wirkungsmodus von Digitalis. Klin. Wochschschrft., 42; 157, 1964 . 47) Simon et al.: Stuides on sodium-potassium-activated adenosine triphosphatase. 2. Formation of aqueous humor. Exp. Eye Res., 1; 253, $1962 . \quad$ 48) Simon et al.: Possible usefulness of cardiac glycosides in treatment of glaucoma. Arch. Ophthal., 68; 227, 1962. Meyer zum Gottesberge et al.: Unterschiede im Metabolism der Schneckenwindungen. Acta Otolaryng., 59; 116, 1965.
教室および耳鼻咽喉科学 教室においてなされ た. 島園順雄教授, 切替一郎教授, 石川晋次講 師, 香川靖婎博士の御指導に感謝する.

本実験はニユーヨーク大学医学部耳鼻咽喉科 学教室において, 著者がレヂデント在任中にな されたＪ．Ｆ．Daly 教授，水越治客員教授， Mr. R. Gore, A.M. Morrison 学士の御協力に 感謝の意を表する.

（原稿到着 $=$ 昭和 41.1 .14 日一急載）

この実験の予備実験は東京大学医学部生化学

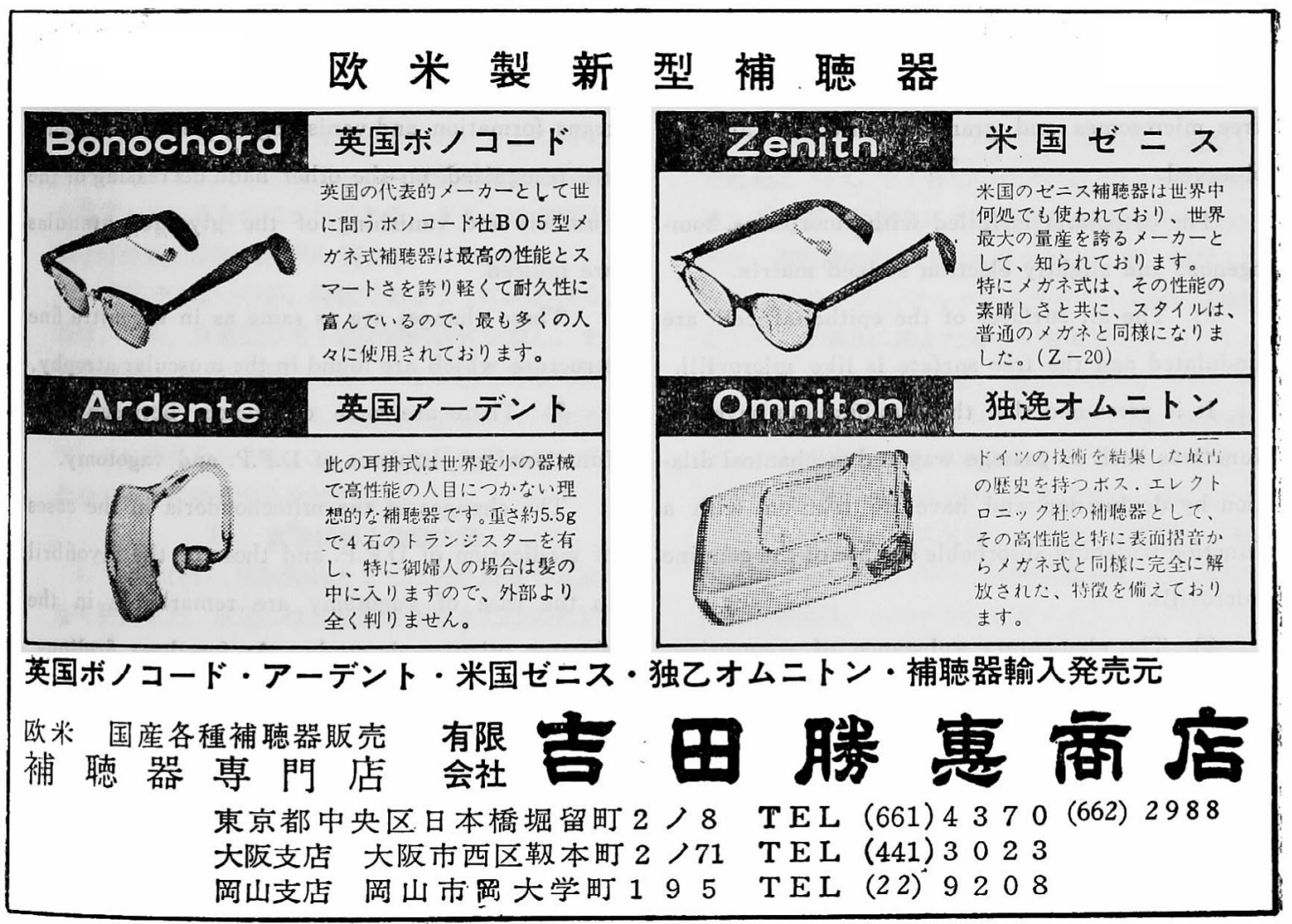

